\title{
REVIEW, RECLASSIFICATION AND DEMARCATING OF CLIMATE IN NEPAL
}

\author{
Puspa Lal Pokhrel PhD (Wetland Scholar) \\ Associate Professor, Central Department of Education Kirtipur Kathmandu
}

Article DOI: https://doi.org/10.36713/epra6094

\begin{abstract}
Geomorphic mountain system of our country (Nepal) is climatically and environmentally unipue. Even Nepal is one of the most ecologically sensivive and fragile area in the mountainous country of the world.Former writer have divided into three to five climatic types of Nepal.This article divided six climatic types. There is an extreme spacious range of climates within very short latitudinal dsistance. The classification, zoning and separating of climate in Nepal is challenging due to complex altitude and topography.The auther is going to discuss this issue on Discourse.
\end{abstract}

Climate plays an important role in natural and cultural landscapes in the surface of the Earth. Climate and weather are the product of atmospheric condition. Though place or relief features of the region, locationand altitude of any place influences the weather and climate they are basically treated as the cycle of atmospheric circulation.

Nepal has Minimum angular distance of latitude so there is least latutudinal effect on climate but due to its Physical features of Land and height of mountain the country experiences various types of climate condition of the earth. It is hot in plains of Tarai, cool in Shivalik ranges, Temperate climate in hills, Cool temperate in Mahabharat hilly ranges, mild cold in sub-Himalayan ranges, and extreme cold climate is Himalayan region. Nepal's climate has been classified in different types by different geographers and scholars. Tony Hagen (1961), Janak Lal Nayabha (1975). Harka Gurung (1968), PP Karan (1980), Prof Saran HariShrestha (1998). Prof. Ram Kumar Pandey (1058) has described Nepal's climate classification along with pictures with due respect to all the above mentioned scholars. The writer presents a new classification after travelling different parts of the country and collecting first hand experience.

It's not practicable to include southern Tarai plain (Bhabhar Tract, Central Tarrai and South Tarai) and Chure hills under the same climatic region.
Similarly, on micro level analysis the location and expansion of Mid Hill Region reveal that it can't represent the whole hilly region in one type of climate condition. That's because, there is a vast difference between the climate of southern slope of Mahabharata Mountain and its northern slope. In the same way, many people of our country consider Lekali region and Alpine climate as same. They consider that alpine climate means the climate found in Lekali Pradesh (High Mahabharat Mountain). The earlier geographers and scholars has classified and explained the climatic condition of 3300 meter to 5000 meter altitude in exactly same with Alps' Mountain Ranges of Europe. But if we study it in micro level, the climate and physical environment of surrounding Alps ranges and environmental condition of Nepal in this altitude has lots of differences. In the Northern part of Alps Mountain there is great plain of Bohemia. Similarly, in the Northern foothills of Alps, there is the dense Black Forest, whereas in the South, there is Mediterranean Sea and Adriatic Sea. There is lots of difference in the climatic condition around the Alps Mountain region and the sub-Himalayan rocky Mountain region (The lower Himalayan belt and the inner Himalayan valley). That's why it is necessary to consider reclassificaton, naming, demarcating and categorizing the climate's types on the context of 
Nepal. The writer has attempted to explain the climate of Nepal in a new way.

\section{METHODOLOGY}

Information for the paper has been collected throw different article about climatic classification of various writers. Similarly the paper about climatic classification of our neighbouring countries like China, India, Bhutan, and Pakistan were reviewed. The study is based on 21 weather stations from Tarai to Himalayan Region of the country. Temperature and precipitation data were taken Department of Hydrology and Meteorology (DHM). The discussion is based on qualitative approaches. Demarcation and zoning of climates are related on mean annual temperature, mean annual rainfall and elevation.

\section{Tropical Monsoon Climate}

Nepal lies in Temperate zone in accordance to horizontal classification of temperature. Though the country, lies in Temperate zone but southern parts of Nepal is lies is near to outer left of northern boundary of Torrid Zone. Horizontal distribution of insolation in the Earth's surface is depending on latitude.The temperature decreases as we go farther to the equator. But, what we should consider is the facts that due to the atmospheric condition of equatorial region, the land area, near to 23.50 North Tropic of cancer and 23.50 South Tropic of Capricorn get the highest amount of insolation. As the atmospheric condition of the region is without cloud and clear, the sunlight come to earth surface without any hindrance and the temperature is more than other latitudional areas.

The Tarai of Nepal is located near the Torrid Zone as the part of Gangetic plain. The Gangetic plain comes under Torrid Zone. Tarai region gets insolation as much as Torrid Zone and it's very hot.We can seperate Tarai by artificial Boundary from Gangatic Plain but physically they are united landmass. Tarai have fully affected by thermal processes (conduction, convection and radiation) which are happening in Gangatic Plain. According to horizontal distribution of temperature, it is include in tropical monsoon climate. But the temperature, nature of Rainfall, weather condition, air pressure and the system of atmospheric circulation of lower troposphere of Tarai, everything is similar to Tropical monsoon climate. Therefore we can't be termed as sub-Tropical monsoon climate of Tarai Region. According to global climatic types the Tropical monsoon climate is spread upto $5^{0}$ to $30^{0}$ latitudes on either side of equator. The huge landmass of Gangetic plain of northern India lies in Tropical monsoon climate. Likewise this region lies in the trade wind belt. The air blows from sea to land for 6 months and vice versa for another 6 months. That's why Tropical monsoon climate is found in Bhabr belt, Tarai plain, inner Tarai, narrow glen and ravine of the Shiwalik ranges.

This type of climate is found in places with elevatioon ranging from 60 meter to 675 meter in terms of altitude. Dun region (InnnerTarai or Vitri Madhesh) means the plain area of foot hills of Mahabharat Mountain surrounded by Chure hills. The plain area of Udaypur, Sindhuli, Makwanpur, Chitwan, Nawlaparasi, Dang Deukhari, and Surkhet districts are experiencing this type of climate. In other words this inner tarai climatic zone is surrounded by Shiwalik hills in South and Mahabharat Mountain in north. This is the hottest and humid region of Nepal. There is $4^{0}$ Celsious temperature differences between Southern boundary of Kechana Lake and Bahundangi of Northern Jhapa which lacated Mechi Municipality.The rainy season starts from $10^{\text {th }}$ June (last week of Jestha) due to south east monsoon. Similarly during winter westerly cyclones too contribute some gentle precipitation, in this region. There is occasionally experience rainfall in March, April and May (Chaitra, Baisakh and Jestha) due to pre-monsoon winds. The region gets monsoon rainfall when South East Monsoon wind pushes with high pressure to westerly wind.

\section{Sub-Tropical Monsoon Climate}

Sub-tropical monsoon climate is found in the altitude from 676 meter of Shiwalik Mountain Range to whole Chure hillly region, inner basins of Mahabharat Mountain, gorges, narrow passage, Taar /Terran firm of inner Mahabhart ranges, confluence of rivers, triple braid (Triweni) altitude upto 1500 meer. It's very hot from April 15 to September 15 (Baisakh to Bhadra) in these basins and lowlands. The average height of Chure is 1500 meters.This climatic region comes between West Seti River and upto Garvachuli area of Doti districts. Mahabharat Mountains are above Chure Mountain or Chure Hilly area. There are many river valleys across Mahabharat Mountain. These river valleys and basins are namely the Madi valley of Palpa, Shera basins of Lamjung, Khimti basins of Ramechhap, Dhuni basins of Dhading, Chutra basins of Arghakhanchi comes under this climatic region. Similarly, this, climate is found in lower and inner parts of Mahabharat ranges, river banks and Terra firms (Taars of hilly region) also has sub-tropical monsoon climate. Among the main Terra firms where this climate occurs, are Beltaar of Udaypur, Rumjataar of Okhaldhunga, Sangutaar of Ramechhap, Salyantaar of Dhading, Jarayotaar of Sindhupalchowk, Khairahitaar of Tanahun, Palungtaar of Gorkha, Chapakottaar of Syanja. According to the weather station of Khairanitaarof Tanahun district, the maximum 
annual temperature and annual average temperature and minimum annual average temperature of this climatic region is $30.2^{\circ}$ celsius, $23.8^{0}$ Celsius, $17.5^{\circ}$ celsius respectively. Similarly, the record of Chaurhajari Taar of Rukum district shows maximum annual temperature is $28.9^{\circ}$ celsius, annual average temperature is $21.8^{\circ}$ celsius, and minimum annual average temperature seems $14.8^{\circ}$ Celsius respectively. According to Khairenitaar weather station, the distrubution of rainfall is 233.33 centimeter ( 2332.24 millimeter).

\section{Warm Temperate Climate}

Warm Temperate climate is found in 1500 to 2500 meter height Mahabharat Mountain Ranges, Midlland, and lower parts of Middle Mountains of Nepal. The temperature might be $20^{0}-30^{\circ}$ celsius depending on height. During summer the days are normally hot and nights are cool. In other words, though it is hot in Midlands, the high Mahabharat Mountains are cool.The summer season, begins from April and ends in September (Baisakh to Bhadra), are very interesting. The winter months are warm in the Mid Hill region whereas, it's very cold in the high Mahabharat Mountain peaks. The winter season remains for four months November to March (Mangsir, Poush, Magh and Falgun) in this region.
During winter season January and February (Poush and Magth), the region gets rainfall due to winter monsoon (westerly) and there is snowfall in high peaks.During the winter rain for few days the high Mahabharat mountain peaks are white by snow. The temperature of this region remain $0^{0}$ to $5^{0}$ Celsius during winter monsoon. The summer monsoon begins from 10th of June. Sometimes the arrival of the monsoon can arrive early or delayed than normal. In 2018 A.D. (2075 B.S) the monsoon was late for 2 days and started from 12th June and in 2019 A.D. (2076 B.S.) Monsoon didn't start n 10th June, instead it started from 20th June (Asar 5). This means monsoon had entered the country on June 20, ten days later than anticipated and ended on October 12. Similarly, monsoon rain of 2020 was begun from 12 June, Saturday evening through from eastern part of Nepal. This year Monsoon has arrived, delayed by two days than anticipated.There is Torrential rainfall in this region during monsoon time. There is more rainfall in the southern slope of Mahabharat Mountains. The entrance of monsoon in Nepal is Jhapa, Morang districts of eastern Nepal. Then after, it collides with eastern mountains then it shift from east to west. The details of rainfall and temperature of this climatic region are given below:

\begin{tabular}{|c|c|c|c|c|c|c|}
\hline Weather station & Year & Elevations & Precipitation & \begin{tabular}{|l} 
Annual \\
average \\
minimum \\
temperature
\end{tabular} & \begin{tabular}{|l} 
Annual \\
average \\
maximum \\
temperature
\end{tabular} & $\begin{array}{l}\text { Annual } \\
\text { average } \\
\text { temperature }\end{array}$ \\
\hline 1. Taplagunj & 2016 & $1732 \mathrm{~m}$. & $2321 \mathrm{~mm}$. & $12.7^{0}$ cels. & $22.9^{0}$ cels. & $17.8^{0}$ cels. \\
\hline 2. Kanyam & 2014 & $1678 \mathrm{~m}$. & $2143 \mathrm{~mm}$. & $20.2^{0}$ cels. & $30.6^{0}$ cels. & $25.4^{0}$ cels. \\
\hline 3. Salleri & 2016 & $2378 \mathrm{~m}$. & $1299.9 \mathrm{~mm}$. & $6.3^{0} \mathrm{cels}$. & $21.8^{0}$ cels. & $14^{0}$ cels. \\
\hline 4. Okhaldhunga & 2017 & $1720 \mathrm{~m}$. & $1579.6 \mathrm{~mm}$. & $13.1^{0}$ cels. & $22.8^{0}$ cels. & $18^{0}$ cels. \\
\hline 5. Charikot & 2013 & $1940 \mathrm{~m}$. & $\begin{array}{l}\text { 2684.4(2017) } \\
\text { mm. }\end{array}$ & $11^{0}$ cels. & $21^{0}$ cels. & $16^{0}$ cels. \\
\hline 6. Nagrkot & 2017 & $2163 \mathrm{~m}$. & $1726 \mathrm{~mm}$. & $10.7^{0}$ cels. & $20^{\circ}$ cels. & $15.4^{0}$ cels. \\
\hline 7. Lumle & 2017 & $1740 \mathrm{~m}$. & $5030 \mathrm{~mm}$. & $12.4^{0}$ cels. & $20.8^{0}$ cels. & $16.6^{0}$ cels. \\
\hline 8. Jumla & 2017 & $2300 \mathrm{~m}$. & $814 \mathrm{~mm}$. & $6.4^{0}$ cels. & $21.6^{0}$ cels. & $14^{0}$ cels. \\
\hline 9. Dadeldhura & 2017 & $1865 \mathrm{~m}$. & $1374.1 \mathrm{~mm}$. & $12.1^{\circ}$ cels. & $22^{\circ}$ cels. & $17^{0}$ cels. \\
\hline 10. Baitadi & 2017 & $1635 \mathrm{~m}$. & $1445.1 \mathrm{~mm}$. & $7.1^{0}$ cels. & $24.8^{0}$ cels. & $15.9^{0}$ cels. \\
\hline
\end{tabular}

Source: Department of Hydrology and Meteorology 2018

Generally there is more rainfall in Eastern Region. The above table shows that Taplejung gets 232 centimeter rainfall. Next to it is Kanyam with 214 centimeter. The places that get most of all rainfall in this climatic regioin are Lumle of Pokhari, which gets $503.04 \mathrm{~cm}$ rainfall. This is the place with heaviest rainfall in whole Nepal. The place that gets least rainfall in their climatic region is Jumla with just 81.4 centimer of rain. It lies at the rain shadow area of Chayakhure Mountains in South. Tha't why it gets least rainfall. As recorded in weather station of Dipal Village of Jumla, the minimum temperature $09^{0}$ celsius to $-4.1^{0}$ celsius from November to February. The maximum temperature is $23^{0}$ to 23. $7^{\circ}$ Celsius in June July and August. 


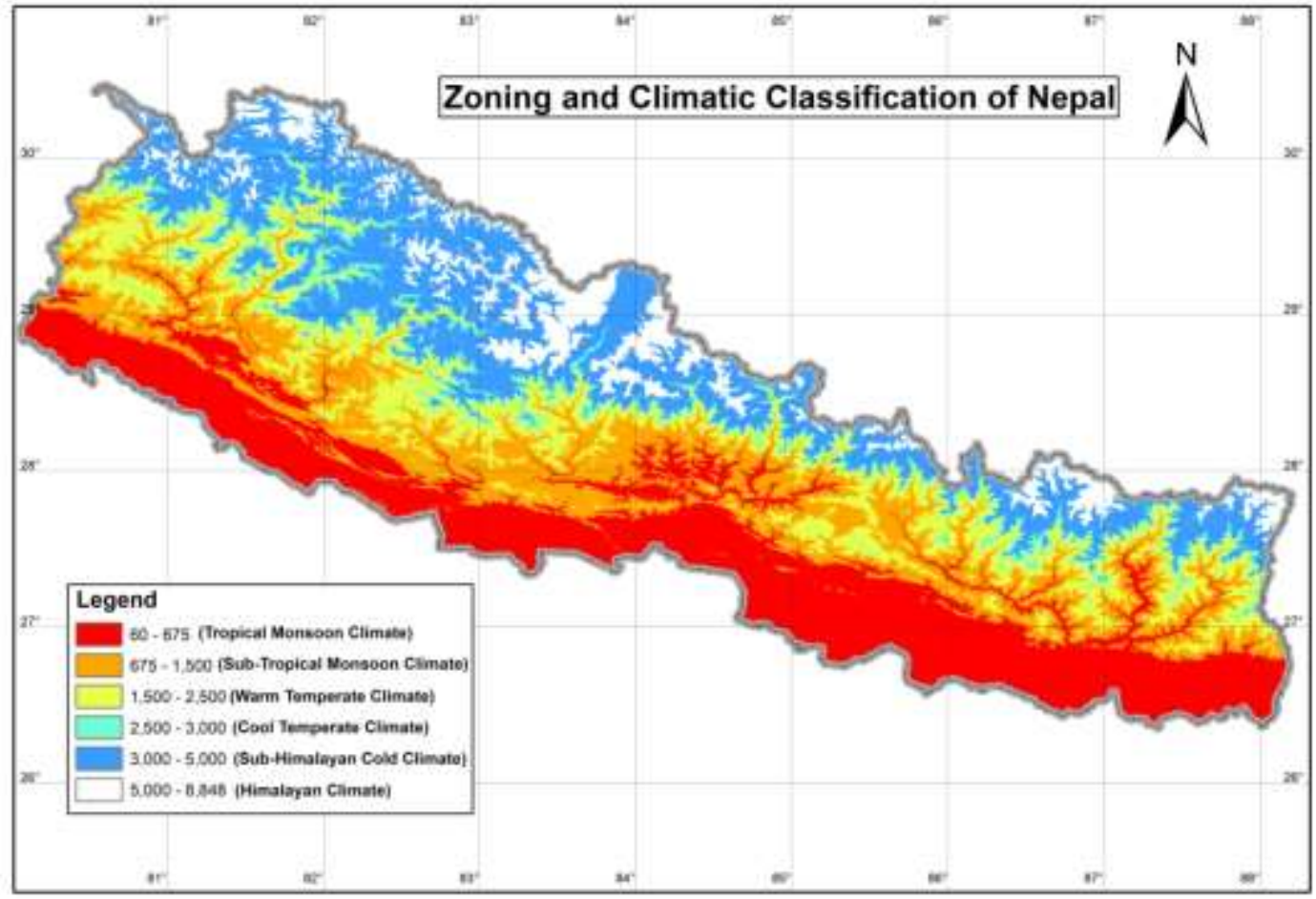

\section{Cool Temperate Climate}

This type of climate is found in the top of the Mahabharat Mountains (Lekali Pradesh) and Lower parts of Himalayan Ranges. Altitudinally Cool Temperate Climate occurs up to about above 2500 meters to 3600 meters. The land between these elevations comes under this climatic region. In the context of Himalayan community of our country, it is more appropriate to term it as Lekali climate because as we move to high altitude, our traditional practice tells us that we have altitude sickness. This is our knowledge by Practices. Traditional Seasonal movement or vertical transhumance of livestock between fixed summer and winter pastures are common in Himalayan culture of Nepal.We have experiencing Lekh Bensi Writu Prawas in ancient times. It implies movement between higher summer pastures in summer and lower valleys in winter. Lekh Bensi lifestyle is a symbol of high mountain region of Nepal
During summer season, May to September the Maximum temperature in Thak Marpha, in Mustang (2566 meter) is from $12^{\circ}$ celsius to $15^{\circ}$ celsius.During winter season. December to February, the minimum temperature is up to $-1.5^{0}$ Celsius to $-3.8^{0}$ Celsius (DOHM, 1997). Similarly, the maximum temperature of Rara Lake, situated in Mugu with a height of 3048 meter is $20^{\circ}$ Celsius to $23^{0}$ Celsius during summer reason (May to September). Its minimum temperature is $60^{0}-11^{0}$ Celsius in summer. Likewise, the winter temperature (December-March) of this region is $8^{0}$ to $14^{0}$ Celsius in the day time and the minimum temperature falls from $-10^{0}$ to $-5.6^{0}$ Celsius in Night. As a result, it is extremely cold in winter, in this region. There is rainfall in winter due to western winds. There is frequently snowfall in winter in this region. During summer, the south east monsoon winds gives rainfall. Compared to leeward North Slope, the windward south slope of mountain has more rainfall. This is clearer with table given below: 
Volume: 9 | Issue: 1 |January 2021 || SJIF Impact Factor (2020): 7.043 || Journal DOI: 10.36713/epra1213

\begin{tabular}{|c|c|c|c|c|}
\hline District & Weather station & Height (M.) & Rainfall (milliliter) & Others \\
\hline Manang & Chame & 2680 & 1320 & \\
\hline Mustang & Jomsom & 2744 & 275.2 & \\
\hline Jumla & Guthichaur & 3080 & 1399.2 & \\
\hline Humla & Simikot & 2800 & 1967.1 & \\
\hline Mustang & ThakMarpha & 2566 & 2566 & \\
\hline Myagdi & Ghorapani & 2742 & 3238.1 & $2641.3(1996)$ \\
\hline Mustang & Summer gaun & 3570 & $303(95)$ & \\
\hline Manang & ManangBhot & 3420 & $472.8(95)$ & $328.1(1996)$ \\
\hline Sankhusabha & Chepuwa & 2590 & 2758.3 & \\
\hline Gorkha & Chhekampar & 3300 & $750.5(2016)$ & \\
\hline Solukhumbu & Chialsa & 2770 & 17.03 & \\
\hline
\end{tabular}

Source: Climatelorical Records of Nepal 1995-2019 (DOHM, Ktm, Nepal)

The rainfall of this climate region decreases from East to west and south to north. There is long winter season (from October to March) in cool temperate climate. The winter season lasts longer with freezing cold. During summer, season also (April, May, June, July, August and September) the daily mean temperatures lowers to $10^{0}, 14^{0}, 15^{0}$, $15.8^{0}, 15.7^{0}$ and $14.9^{0}$ Celsius respectively. As a result, the summer season is just warm only, during winter, the peaks of this mountain region is totally white, due to snow fall. Depending on the height of the peaks, it snow clad for weeks and even months. During winter season the cold wind blows from Himalayan mountain of North to South. This extreme cold breeze is called Siretoo.

In this climatic region, somewhere it is cold, somewhere it is humid, somewhere, it is dry depending on the height, altitude, and wind ward and leeward location of Mountain Ranges. This climatic region is very beautiful and healthy from natural and environmental point of view. This area is famous for it big storehouse of colouful flower and medicinal herpes. It is very rich in its diverse biological character.

\section{Sub-Himalayan Cold Climate}

This type of climate is found in Nepal's northern area situated in sub-Himalayan Mountain Stony Region with the height 3600 meter to 500 meter. This is also known as Sub Himalayan cold climate. This climate region includes lower belt of Himalan Region, Dolpa, Manang and Mustang, area that is situated at beyond the Himalaya or accross the Himalaya, this dissected and uneven land below permanent snowline. Depending on the height of the sub-Himalayan climatic region is covered by snow in winter for three to six months.During winter subhimalayan peaks, Himalayan Pasture and gradzing land (Kharka and Patan) are also covered by snow.

During Summer and Rainy season, the area is transformed into a beautify grazing land as the snow melts. This stony environment only grasses and shrubs can grow and survive here.

This area is very attractive for internal and external tourists during During mid April to mid August (Baisak to Shrawan). In this climate region, the summer season is very short and just warm only to be clear. It is sub-Himalayan grassland area. During winter and autumn season there is no human activity. Other seasons are suitable for cowherds, shepherds and tourists. There is scarcely spread human inhabitants are found around river banks.

The winter season lasts for seven months in Lhomanthang, Mustang (3705 meter) of this SubHimalayan Cold Climate Region. The winter season begun from October and lasts upto April. The minimum temperature of winter season can drop upto $0.3^{\circ}$ celsius in October, $-6.7^{0}$ celsius in November $11.7^{\circ}$ celsius in December, $-6.1^{\circ}$ censius in March, and $-1.4^{0}$ celsius in April. The summer season begins from May and end with September. The minimum temperature in summer season ranges from about $2^{0}$ to $9.9^{\circ}$ celsius. The maximum temperature occurs $16^{0}$ $-20.5^{\circ}$ celsius. There is 27 millimeter to 49 millimeter rainfall in this climatic region.

On the other hand, Chosher weather station situated 3870 meters elevation in Dlopa, records that the nearby area's Annual Average minimum Temperature as $0.1^{0}$ to $0.5^{0}$ Celsius. Similarly, annual average maximum temperature as $14.4^{\circ}$ and Annual average temperature 7.40 celsius. According to record of Chosher weather station in 2017 A.D. theare has $269.4 \mathrm{~mm}$. rainfalls.

During the westerly depressions contribute rain in the form of snow. There is snow storm during rain. During the winter of 2018 (2075 B.S), Western wind had carried snowfall upto the lower boarders of 
this climatic region. There is no even distribution of rainfall in this climatic region. Snowfall is very normal during winter in the region. There are large and slopy grasslands in this climatic region. These huge Himalayan Grasslands are above Timeber line Timber line lies at 4300 meters. Vegetation like stunted conifers, shrubs, flowery plants and medicinal herbs like Tibetan spice (Jimbu Jhar) are plenty in this region. There are stunted conifers spread thinly. This climatic region is not suitable for agriculture. In the lower Himalayan part, there is a little bit, plantation like potatoes, barely buckwheat etc. Semi arid valleys including Humla, Jumla, Dolpa, Mustang and Khumbu are can be include in this belt.This climatic region is appropriate for keeping animals like Himalayan cow, sheep, horse, goats etc. Though some of our earlier geographers and scholars have explained this region as Alpine climate, but the environmental condition and atmospheric condition of the area surroundings the Alps is completely different with this sub-Himalayan landforms. There is sea near to Alps Mountains. That's why it is appropriate to call this area as subHimalayan cold climate (Laghu Himali Hawapani), in the context of our country. It sketches the real picture of stony region of Nepal above 3600 meter to below 5000 meter.

\section{Himalayan Climate}

The region above the snowline of Himalayan ranges are called Himalayan climate. This climate is found above 5000 meter to Mount Everest's peak. This region is permanently covered by thick snow layer. In the Himalayas the permanent snow line can be as high as 5000 mertres to 5,700 metres. The snow line is fluctuating on season. The snowline is retreating.Generally; the snowline elevation is lower in the west than in the east, although the central region shows relatively lower snowline elevation, not following the general zonal trend (A. B. Shrestha \& S. P. Joshi 2009).

The temperature of this region is below freezing point throughout the year. It is extremely cold throughout the year. In this climatic region, the rain falls as snow. The water vapour particles of atmosphere of this climatic region freezes in the air/sky, due to extreme cold and falls in the Himalayan region as snowfall. Rocky and stony grounds are perennially frozen and surface and subsurface of the soil is permanently frosted, at this physical environlment permaforest is developed. Permaforest means the freezing condition of all materials in the deep of soil or rocks. So, the soil is prrmanent Frozen in this region. The absolute Humnidity is very low in this region. Mostly, there is snow storm after mid day, in this climatic region. In terms of natural vegetation, Cold Desert Environment is found in thyis climatic region. Vegetations can't grow and develop due to Periglacial environment. Along with this, amount of Insolation's very low in this region. As a result, only mosses and Lichens are found in very few places. This climatic region is situated in very high altitude, so, atmospheric presssure is very low here. It's because there is an opposite relation between the height and atmospheric pressure. As the height of the place increases, atmospheric pressure decreases. That's why there is lack of oxygen in high altitudes. It causes mountain sickness to new comer, travellers, and tourists from different environmental condition coming to this region. If a person has headache, nauseous, vomiting etc., while travelling to this region, she / he must hurry to the low/lands. The climate and environmental condition of this climatic region is similar to the climate of polar region. This climatic region stores more snow and ice than anywhere in the world except for the North and South Poles, therefore giving it the name the Third Pole. Climate change is now a key concern in the Himalayan environment. The rate of warming in the Himalayan Region is considerable more than the worldly average, and the rate is increased at an elevated altitude, indicating a more susceptibility of the cryosphere environment to climate change. This trend is expected to continue. Marsal Kruz had first Investigating and experiencing the Himalayan Environment then named this climatic region as Third Pole in 1933 A.D.This region is also known as ice cold climate because the environmental condition of this region drops to below freezing point. Some earlier geographer and climatologists and contemporary scholars have explained this climate region as Tundra climate. This explanation can not sketch the real picture of our Himalayan climate. The literal meaning of Tunder is Barren land, that is, unfertile unproductive and rough land. There are plenty of Shrubs, Algae, Salix Herbacea and Salix arctica is Tundra region. In Arctic Tunda Climatic Rregion, there are 66 families of Algal, fungi and mosses that are found in Cryophytes climate. In active Tunder region there is 50 days cool summer reason for plant growth. The life cycle of vegetation's found in this region is complete within this short period of time. In other words, the whole process of growth of plant tissues, flowering, pollination, repending of seeds, and dispersal of seeds is complete with 50 days. This type of environmental condition is not present in our Himalayan Environment. That's why, its not appropriate to call this climatic region as Tundras. Similarly, the type of water birds and Wild life found in tundra region is not found in our Himalayan environment. Waterfowl, duck, swan, different species of geese and in animal 
species, reindeer, caribou etc. are found in Tundra Region, but not in our Himalayan region. Considering all these facts, it can be concluded that Tundra climate cannot represent our Himalayan climatic region above 5000 metre. That's why this climatic region should be called Himalayan climatic region now on words.

\section{CONCLUSIONS}

The climatic of Nepal has been classified by different writers and in different method and way. But these classifications did not represent real picture of our different landscapes. Altitudinal differentiation, along the low river basin, deepist valley, densely forested area in the south and north of Subhimalayan Region lofty mountains in the north frontier, Mountain direction and slope of land are typical features of Nepal and these environmentala and Phisical factores have strong bearing on the local and regional climatic conditions. The observation and the spatial analysis of temperature and precipitation indicate significant variations in the climatic classification of diffirent places of the country. Spatial and temporal pattern of temperatlure and rainfall reflect the influences of altutudinal variations. There is vast differential conditon of climate in south and notth facing slope of the mountains.

\section{Acknowledgement}

The author is thankful to Prof.Dr Kabi Prasad Pokhrel, Prof. Dr. Shambhu Khatiwada and Dr.Devi Prasad Poudel for providing valuable suggestion and comments.

\section{REFERENCES}

1. Hagen, Tony (1970). The Kingdom on the Himalayas. New Delhi.

2. Husain Majid (2008). Geography of India. Tata McGraw-Hill Publlishing Company Limited. New Delhi.

3. Karan Pradyumna Prasad (1960) Nepal-A Cultural and Physical Geography, University of Kentucky Press, Lexington, 1960

4. Nayava J. L. (1975). Climate of Nepal. The Himalayan Review, Nepal Geographical Society Kathmandu vol. VII, No. 7

5. Nayava J.L (1980). Rain fall in Nepal. The Himalayan Review, Nepal Geographical Society vol. 12: p.1-18

6. Pande Ram Kumar (2058). Nepalko Bhautik Bhugol. Vidyarthi Pustak Bhandar. Kamalokhari, Kathmandu.

7. Shrestha Arun Bhakta and Sharad Prasad Joshi (2009). Snow Cover and Glacier Change Study in Nepalese Himalaya Using Remote Sensing and Geographic Information System. Journal ofHydrology andMeteorology, Vol.6, No. 1
8. Shrestha Sharan Hari (2004). Educational Publishing House. Jamal, Kathmandu

9. Yong Luo, Dahe Qin, Renhe Zhang, Shaowu Wang and De'er Zhang (2016). Climatic and Environmental Changes in China. Chinese Academy of Meteorological Sciences, China Meteorological Administration, Beijing, China.

10. Jing'ai Wang, Honglin Xiao, Rudi Hartmann and Yaojie Yue (2014). Physical Geography of China and the U.S.

11. Yong Luo, Dahe Qin, Renhe Zhang, Shaowu Wang and De'er Zhang (2016). Climatic and Environmental Changes in China. D. Qin et al. (eds.), Climate and Environmental Change in China: 1951-2012, Springer Environmental Science and Engineering, DOI 10.1007/978-3662-48482-1_2. Springer-Verlag Berlin Heidelberg

12. Shahnawaz and Josef Strobl (2015). A Zonal Analysis of the Climatic Conditions in Bhutan. Occasional Publication No. 1, September 2015. Centre for Rural Development Studies, College of Natural Resources, Lobesa, Royal University of Bhutan. 